\title{
Горева М.В.
}

\section{Подготовка к школьному обучению как психолого-педагогическая проблема}

\author{
МКДОУ Чухломский детский сад "Родничок"
}

(Россия, Чухлома)

doi 10.18411/sciencepublic-04-05-2020-21

idsp sciencepublic-04-05-2020-21

\section{Аннотация}

В статье рассматриваются основные подходы к изучению проблемы подготовки ребенка к школьному обучению, компоненты готовности ребенка к обучению в школе, а так же психолого-педагогическое сопровождение как технология подготовки к школьному обучению.

Ключевые слова: подготовка к обучению, готовность к обучению, ребенок дошкольного возраста, дошкольное образовательное учреждение, психологопедагогическое сопровождение.

Одним из важных этапов социализации личности является период обучения в школе, который предъявляет требования к развитию у ребенка организационных, мотивационных, социальных и личностных характеристик, позволяющих ему успешно адаптироваться к изменившейся социальной ситуации развития и новой роли обучающийся. Таким образом, подготовка ребенка к школьному обучению является актуальной психолого-педагогической проблемой.

В настоящее время существует несколько определений понятия «подготовка к школьному обучению». А.В. Петровский определяет готовность к школьному обучению как совокупность морфофизиологических особенностей ребенка старшего дошкольного возраста, обеспечивающую успешный переход к систематическому, организованному школьному обучению [4]. В.С. Мухина рассматривает готовность к школьному обучению как потребность и осознание ребенком необходимости учиться, возникающее в результате его социального созревания, а так же появления у него внутренних противоречий, задающих мотивацию к учебной деятельности [7]. Е.Е. Кравцова рассматривает подготовку ребенка дошкольного возраста к обучению в школе как его подготовку к возможности полноценного освоения в дальнейшем следующих компонентов учебной деятельности: выделение, конструирование, планирование, принятие, поиск решения, контроль и оценка результата [4]. В трудах Л.А. Венгера подготовка детей к школьному обучению рассматривается с точки зрения целенаправленного формирования у них предпосылок учебной деятельности. Автор подчеркивает, что подготовка к школьному обучению заключается не в том, что у ребенка к моменту поступления в школу сформирована система знаний, умений и навыков, а так же определенных образцов поведения и деятельности, а в том, что ребенок имеет предпосылки к успешному их усвоению в будущем [6].

И.В. Юнгман называет ряд компетенций, которыми должен владеть ребенок к моменту поступления в школу - интеллектуальная, эмоциональная и социальная зрелость. К интеллектуальной зрелости относят уровень развития психических познавательных процессов, позволяющий ребенку осваивать программу начального общего образования, включающий произвольность восприятия, внимания, памяти и мышления. Эмоциональная зрелость включает эмоциональную устойчивость и отсутствие у ребенка импульсивных реакций. Социальная зрелость дошкольника включает в себя подчинение правилам детского коллектива, коммуникативные навыки ребенка, позволяющие ему выполнять роль ученика, умение принять на себя эту роль [Ошибка! Источник ссылки не найден.].

Выделяют следующие виды готовности дошкольника к обучению в школе: психофизиологическую, интеллектуальную и личностную. Психофизиологическая 
готовность ребенка к обучению в школе - это определенный уровень физического развития ребенка, включающий уровень зрелости мозговых структур, состояние основных функциональных систем организма, состояние здоровья ребенка, которые обеспечивают соответствующее возрастным нормам функционирование психических процессов. Интеллектуальная готовность к обучению в школе - это необходимый уровень развития психических познавательных процессов у ребенка, а так же имеющихся у него знаний. Компонентами личностной готовности ребенка к обучению в школе являются: мотивационная готовность, эмоционально-волевая готовность и коммуникативная готовность [2].

Содействие процессу подготовки ребенка к школьному обучению является приоритетной задачей деятельности дошкольного образовательного учреждения, в условиях которого происходит формирование предпосылок учебной деятельности и развитие социально-психологических особенностей личности. В условиях детского сада целесообразно создание специальной среды, содействующей развитию способностей, познавательной активности, эмоционально-волевых качеств, мотивационных свойств ребенка [7].

Среди направлений деятельности дошкольного образовательного учреждения по подготовке детей к школьному обучению называют: содействие общему развитию ребенка, воспитание произвольности поведения и деятельности, формирование мотивации учебной деятельности. Для решения данных задач используются различные формы и методы: игры, экскурсии, коррекционно-развивающие занятия, музыкальные занятия, занятия, направленные на развитие физической активности, занятия лепкой, художественным творчеством [5].

Одной из комплексных технологий, применяемых в процессе подготовки детей к школьному обучению, является технология психолого-педагогического сопровождения.

Н.И. Гуткина определяет психолого-педагогическое сопровождение детей в период подготовки к школьному обучению как процесс совместной деятельности педагога-психолога и ребенка, осуществляемый в диагностических, прогностических, информационных, адаптационных, консультационных, реабилитационных и иных целях, позволяющих своевременно выявлять проблемные ситуации воспитанников и оказывать им своевременную помощь и поддержку в их решении [1].

Технология работы педагога-психолога по сопровождению процесса подготовки детей к обучению в школе включает следующие этапы: подготовительный этап; этап первичной диагностики готовности детей к школьному обучению; этап реализации психолого-педагогических мероприятий по повышению уровня подготовки детей к школьному обучению; этап вторичной диагностики готовности детей к обучению в школе. В рамках реализации данных этапов применяются такие формы и методы, как: опрос, анкетирование, тестирование, наблюдение, беседа, анализ психологопедагогической документации, проективные методы, анализ продуктов деятельности, игра, тренинг, упражнение, арт-терапевтическая работа, консультация, информационно-просветительская работа [3].

Таким образом, можно сделать вывод о том, что подготовка к школьному обучению является актуальной психолого-педагогической проблемой. Готовность к школьному обучению - это совокупность физиологических, интеллектуальных и личностных особенностей ребенка, необходимых для его успешной адаптации к условиям общеобразовательного учреждения и успешной учебной деятельности. Выделяют психофизиологический, интеллектуальный и личностный виды готовности дошкольников к обучению в общеобразовательной организации. Одной из комплексных технологий, применяемых в процессе подготовки детей к школьному обучению, является технология психолого-педагогического сопровождения, способствующая развитию социального, личностного и интеллектуального потенциала 
ребенка, который является предиктором успешности его обучения в школе и адаптации к условиям общеобразовательной организации.

$$
\text { *** }
$$

1. Большакова Л.С. Психолого-педагогическое сопровождение детей старшего дошкольного возраста в период подготовки к школе / Л.С. Большакова // Международный студенческий научный вестник. - 2016. - №5-2. - С. 18-20.

2. Григорьева Г.Г. Проблемы подготовки детей к школе в системе современной модернизации дошкольного образования / Г.Г. Григорьева // Современное дошкольное образование. Теория и практика. - 2010. - №1. - С. 52-58.

3. Казанова А.А. Психолого-педагогическое сопровождение детей в период подготовки к обучению в школе / А.А. Казанова // Цивилизация знаний: ХХ Международная научная конференция. - 2019. C. 507-512.

4. Модина И.А. Культурно-исторические основания психологической готовности к школьному обучению / И.А. Модина // Достижения науки и образования. - 2018. - №1. - С. 55-56.

5. Стригунова А.Г. Педагогические условия подготовки детей к школе в дошкольных образовательных учреждениях / А.Г. Стригунова // Молодой ученый. - 2016. - №10. - С. 1290-1293.

6. Чепцова Н.А. Готовность к обучению в школе: понятие, история проблемы [Электронный ресурс]. - URL: https://superinf.ru/view_helpstud.php?id=2096 (дата обращения 23.04.2020).

7. Юнгман И.В. Психологические проблемы готовности детей дошкольного возраста к обучению в школе / И.В. Юнгман // Актуальные задачи педагогики: материалы VI Междунар. науч. конф. (г. Чита, январь 2015 г.). - Чита: Молодой ученый, 2015. - С. 58-60.

\section{Григорьева Л.А. \\ Социально-психологические условия развития стрессоустойчивости студентов- юристов \\ ФГБОУ ВО «Иркутский Государственный университет»} (Россия, Иркутск)

doi 10.18411/sciencepublic-04-05-2020-22

idsp sciencepublic-04-05-2020-22

Актуальность исследования социально-психологических условий развития стрессоустойчивости студентов-юристов обусловлена, главным образом, тем, что профессиональная деятельность юристов в психологическом плане входит в группу профессий с большим присутствием стрессовых факторов. Один из критериев профессионализма юристов - умение работать с разными людьми, сохранять спокойствие в любой конфликтной ситуации. Соответственно, студентам-юристам необходимы навыки профилактики и преодоления стрессовых ситуаций, создания условий для психологической защиты от негативного стресса и фрустрации [7].

Психолого-педагогические подходы к рассмотрению понятия «стрессоустойчивость» и «условия развития стрессоустойчивости» изучены такими авторами, как В.А. Бодров[1], Р. С. Лазарус[6], Г. Селье[9], С.В. Субботин[10], Б.Х Варданян[2], П.Б. Зильберман[3], И.В. Малышев[8], и др.). Основные положения о психологических особенностях студентов-юристов были рассмотрены в работах В. А.Карбузовой, Н. В. Шамиловой[4], В.В.Криштоп, О.С. Ленчер [5],О.В. Лозгачевой[7].

По мнению С.В. Субботина, стрессоустойчивость - «уникальная психологическая особенность, заключающаяся в специфической взаимосвязи различных свойств индивидуальности, что дает биологический, физиологический и психологический гомеостаз системы и ведет к оптимальному взаимодействию субъекта с окружающей средой в различных условиях жизнедеятельности»[10, С.12].

Б.Х Варданян предлагал понимать стрессоустойчивость как «деятельностный и личностный показатель» [2, С.140].

П.Б. Зильберман определяет стрессоустойчивость как «свойство личности, которое характеризуется взаимодействием эмоциональных, волевых, интеллектуальных 